\title{
Efficacy of Different Types of Written Corrective Feedback on EFL University Students' Writing Quality
}

\author{
Sultan H. Alharbi ${ }^{1}$ \\ ${ }^{1}$ Department of English Language \& Translation, College of Languages \& Translation, King Saud University, \\ Riyadh, Saudi Arabia \\ Correspondence: Sultan H. Alharbi, Department of English Language \& Translation, College of Languages \& \\ Translation, King Saud University, Riyadh, Saudi Arabia. E-mail: suhalharbi@ksu.edu.sa
}

Received: May 10, 2020

Accepted: June 7, $2020 \quad$ Online Published: June 23, 2020

doi:10.5539/ijel.v10n4p217

URL: https://doi.org/10.5539/ijel.v10n4p217

\begin{abstract}
The present study sought to examine the relative efficacy of three different types of written corrective feedback, as well as feedback compared with no feedback, in the context of responses to student writing quality. This study involved 60 students from the Department of English Language and Translation in the College of Languages and Translation at King Saud University. The students were divided into three groups of 20 students each. There were two experimental groups (Group A and Group B) and one control group (Group C). Groups A and B received direct and indirect written corrective feedback, respectively, while Group $\mathrm{C}$ received minimal written corrective feedback. The subjects were evaluated through pre- and post-tests. The study also aimed to explore the attitudes of the subjects about the different forms of written corrective feedback and attempted to find whether there was any relationship between the subjects' attitudes and the actual effects of the types of written corrective feedback on their writing. Results showed that among the three types of feedback, direct written corrective feedback was the most effective in improving students' writing quality, and that this form of feedback was the most preferred by the subjects. The pedagogical implications were discussed, limitations of the study were presented, and suggestions for further research projects were proposed.
\end{abstract}

Keywords: written corrective feedback, writing quality, EFL university students, direct/indirect feedback

\section{Introduction}

Feedback is essential to develop students' academic writing skills (Hyland \& Hyland, 2019). Feedback is defined as a teacher's response on a piece of writing providing information to be employed in making revisions (Keh, 1990). A further definition is that feedback is the way in which teachers' responds to the writing of students either orally or in writing with the intention of assisting them in improving the quality of their writing (Keh, 1990; Nicol \& Macfarlane, 2006). Feedback can be either written or oral. Two main forms of written corrective feedback (WCF) exist: direct and indirect. Direct WCF is a form of correction that shows students where they have made errors and offers them the correct alternative, i.e., the teacher highlights the error and supplies the correct form for the student. In contrast, indirect WCF involves highlighting errors for students but not giving them any correction (Bitchener \& Ferris, 2012). Alternatively, there are many different types of oral feedback (Park, 2010) such as one-to-one conferencing (Williams, 2002) and positive or negative oral recasts (Afitska, 2015; Lyster \& Ranta, 1997). This study focuses on WCF as opposed to oral feedback.

In Saudi Arabia, writing is taught as part of the language skills courses in the English departments of universities. At the Department of English Language and Translation (DELT) in the College of Languages and Translation (COLT) at King Saud University (KSU), writing is offered as a series of three courses: Writing I (paragraph writing), Writing II (review of paragraph writing and introduction to essay writing), and Writing III (essay writing and summary). According to the researcher's personal experience as a writing teacher, many university writing teachers complain about English as a foreign language (EFL) Arab students' inability to write well, and therefore most of these students score badly on writing examinations (Ahmed, 2020). Indeed, the difficulties that these students encounter in writing classes have been observed at several other Saudi universities (AbuSeileek, 2006; Al-Hazmi \& Scholfield, 2007; Alhaysony, 2008)

A growing number of studies (e.g., Alharbi, 2016; Alkhatib, 2015) have therefore been carried out to examine the problem of EFL students' inability to write effectively at the university level in Saudi Arabia in order to find a 
solution. These studies have aimed, among other things, to ascertain the effectiveness of teachers' WCF on helping students improve their writing quality. For example, Alharbi (2016) indicated that teachers' WCF had a significant positive influence on students' writing performance and that students showed positive attitudes towards feedback from their teachers. The current study will thus build on Alharbi (2016) and examine the impact of three different WCF forms (direct, indirect, and minimal feedback) on students' writing achievement. Katayama (2007) also noticed that the focus of most studies was on investigating the effect of feedback on students' writing and neglected to explore students' attitudes towards WCF. Therefore, this study will also evaluate Saudi students' attitudes towards these three WCF types. Writing teachers should be aware of the attitudes of their students for the types of WCF they give, because students' preferences can affect the usefulness of the provided WCF (Amrhein \& Nassaji, 2010) and may enhance their engagement and enthusiasm (Hamouda, 2011). Another aim of the current study is to identify the relationship between students' attitudes and the actual effects of the three different WCF types on their writing. Writing teachers should not only distinguish the most beneficial types of feedback and the most preferred feedback by students, but also try to align the two factors in order to improve students' motivation, learning, and behaviour in class (Ferris, 2003).

\section{Literature Review}

Research has demonstrated that WCF has a positive influence on the quality of student writing (e.g., Alharbi, 2016; Bitchener \& Knoch, 2009a; Chandler, 2003). Some studies have also found that direct and indirect WCF were both effective in improving the accuracy of student writing (e.g., Bitchener \& Knoch, 2009b; Ferris \& Roberts, 2001), although it has generally been found that direct WCF has the greater influence in terms of improving overall accuracy and long-lasting effects (e.g., Aghajanloo, Mobini, \& Khosravi, 2016; Beuningen, Jong, \& Kuiken, 2012; Van Beuningen, De Jong, \& Kuiken, 2008). Research has also shown that the effect of direct WCF in terms of writing accuracy is enhanced when used in combination with additional forms of feedback (e.g., Suzuki, 2012). Additionally, there has been some research into students' preferences and attitudes towards the types of feedback they are provided with (e.g., Al-Sawalha, 2016; Hamouda, 2011; Katayama, 2007; Korte, 2015; Salteh \& Sadeghi, 2015; Srichanyachon, 2012; Zacharias, 2007). In this section, I will review in some detail a number of the related investigations on the topic of this study.

Ferris and Roberts (2001) investigated whether WCF (either marked using codes or underlining without comment) is beneficial at higher or lower levels of explicitness and for seeing how it affects the accuracy and general quality of student writing. The results demonstrated that while both experimental groups became more accurate in writing and produced a better quality of writing than the control group, there was no difference between the experimental groups. These researchers (ibid.) came to the conclusion that WCF improves writing accuracy to the same degree whether it is explicit or not. Chandler (2003) studied the influence of WCF on the writing vocabulary and grammar of students. 31 students were split into a control group (16 students) and an experimental group (15 students). These students took two classes per a week to improve their English reading and writing skills. The results indicated that the experimental group significantly improved their writing accuracy in comparison to the control group, leading to the conclusion that writing accuracy can be improved using WCF.

Alharbi (2016) examined the influence of teacher's WCF on the quality of writing of male EFL university students in Saudi Arabia. 25 students were assigned to a control group and 25 to an experimental group. The data collection for the study lasted over two months, using a pre-/post-test design for matching groups. The results indicated that the experimental group showed a higher level of performance than the control group, demonstrating that teachers' WCF significantly and positively influences the quality of student writing. Alharbi also showed that EFL university students reacted positively to WCF from their teachers, and this in turn had a positive influence on their approaches to the learning of writing skills. Mubarak (2013) investigated the effectiveness of both direct and indirect WCF. Mubarak (2013) divided 46 Bahraini university students into three groups: two experimental groups, one receiving direct WCF and one receiving indirect WCF, and one control group. The control group was not given any correction, just simple summative performance comments. The evaluation of students' achievements was undertaken through pretesting, post-testing, and delayed post-testing. The study found that although students did show improvement over the course of the experiment, neither form of WCF significantly influenced accuracy or grammatical/lexical complexity in written work, and neither form of feedback was demonstrably more useful than the other.

Bitchener and Knoch (2009a) conducted a 10-month investigation into the influence of three different forms of WCF on the writing accuracy of students through measurement of the ways in which they employed two different English articles: the definite article "the" and the indefinite article "a". A cohort of 52 students was split at random into four different groups of 13 students. While all the three experimental groups demonstrated better 
performance than the control group by the given measure, they did not differ significantly in performance compared to each other. Bitchener and Knoch (2009a) concluded that WCF was beneficial to developing student writing accuracy in using the two articles chosen on a long-term basis, though no specific form of WCF demonstrated significant advantages compared to any other. Beuningen et al. (2012) researched the effectiveness of both direct and indirect WCF in terms of students' overall accuracy, grammatical accuracy, non-grammatical accuracy, grammatical complexity, and lexical diversity in writing. A cohort of 268 students was divided into four groups (two experimental groups and two control groups). While one experimental group was given direct WCF through corrections written below errors, the other experimental group was given indirect WCF by being shown where each error was and what type of error it was with symbols and codes (e.g., "S" for spelling errors). The first control group of students was not given any feedback and were asked to revise and correct their compositions themselves, whereas the second control group were given no feedback but instead were given new writing tasks. In terms of overall accuracy, it was found that direct WCF had a greater influence than indirect WCF, with the first experimental group outperforming the second.

Bitchener, Young, and Cameron (2005) examined the influence of direct WCF combined with student-teacher meetings in terms of overall accuracy and accuracy in correctly employing definite articles, prepositions, and simple past tense. While the results did not reveal any significant variations in terms of overall accuracy, the experimental group (receiving direct WCF/meetings) showed significantly better performance in deploying the definite article and simple past tense. The study suggested that a combination of direct WCF and one-on-one meetings can improve accuracy of the definite article and simple past tense. The study also concluded that direct WCF combined with one-on-one meetings would have a more significant influence than indirect WCF on accuracy in the long term. Binglan and Jia (2010) studied the effectiveness of direct WCF combined with explicit explanations in improving writing accuracy over the long term. Binglan and Jia's study selected a cohort of 44 second-year Chinese EFL students at Hefei University majoring in mathematics or computer science. These students were of comparable proficiency in English. The computer science students were placed in an experimental group, and the mathematics students were placed in a control group. The results indicated that the experimental group showed a significantly higher level of writing accuracy in general than the control group. The researchers concluded that a combination of direct WCF and explicit written guidance led to improvements in student writing accuracy.

Al-Sawalha (2016) investigated the attitudes towards written feedback of 20 English language bachelor's students at a Jordanian university. The study found that although there was a variety of attitudes from students regarding their teachers' WCF, most students stated that they found WCF from their teachers to be beneficial. Moreover, the study demonstrated that both revision skills and overall writing quality of the students improved when they received WCF from their teachers. Hamouda (2011) used questionnaires to research the preferences and attitudes of both Saudi EFL students and teachers regarding written error corrections. Hamouda demonstrated that both students and teachers held positive attitudes regarding written corrections and that although students were in favour of overall corrections, teachers were not. It was also observed that students found teachers' corrections preferable to self-correction or peer correction.

Even though the relevant literature suggests that WCF is beneficial for improving student writing quality, there are some varying results regarding the effectiveness of direct and indirect WCF in increasing the quality in student writing. Moreover, it also seems that very few studies have been carried out in the Arab world in order to investigate the impact of different types of WCF in developing students' achievement in writing (Ahmed, 2020; Mubarak, 2013). Therefore, the current study aims to make a contribution to the literature by investigating the effectiveness of different forms of feedback on the writing performance of Saudi EFL university students. In particular, the current study seeks to answer the following research questions:

- Is there any significant difference in the effects of three different types of WCF (i.e., direct, indirect, and minimal feedback) in helping students improve their written drafts?

- Is there any significant difference in the attitudes of students about the three different types of WCF (i.e., direct, indirect, and minimal feedback)?

- Is there any relationship between students' attitudes and actual effects of the three WCF types (i.e., direct, indirect, and minimal feedback) in students' writing?

\section{Methodology and Procedures}

\subsection{Participants}

The current study was conducted at DELT in COLT at KSU. 60 male Saudi EFL undergraduate students 
participated in this study. The students enrolled in Writing III course as a part of their bachelor's degree requirements in the second term of the academic year 2018/2019. The students at DELT are required to pass Writing I and Writing II courses before enrolling in Writing III. The rationale for selecting the students enrolled in Writing III course was to ascertain the homogeneity of their English writing proficiency levels. Also, compared to students enrolling in Writing I and Writing II courses, students in Writing III course already have some knowledge of English and writing and, therefore, it is not difficult for them to understand and benefit from the feedback provided (Ferris, 2011). The 60 students were randomly divided into three groups (two experimental groups and one control group, 20 students in each). Groups A and B received direct and indirect WCF, respectively, whereas the control group (Group C) did not receive any WCF but minimal feedback.

\subsection{Treatment: Teaching and Feedback Procedure}

The three groups of students were taught for 13 weeks and were asked to write one essay every week. The first experimental group (Group A) was given direct WCF on every essay. Every error was corrected in red ink. The essays were then returned, and the students instructed to re-draft and re-submit them. The new essays were corrected again, photocopies were made, and the essays were again returned to the students, this time with instructions to read the corrections. This process was followed for the whole period of the treatment (i.e., 13 weeks). The second experimental group (Group B) was given indirect WCF, with errors in each essay underlined and a note made as to the type of error. For each essay, errors were underlined in red ink with a short description in the margins or over the error. The essays were then returned, and the students instructed to re-draft and re-submit. These new essays were then corrected again, photocopies were made, and essays were again returned to the students, this time with instructions to read the corrections. This process was followed for the whole period of the treatment (i.e., 13 weeks). Group C (the control group) received no WCF on their essays for the whole 13 weeks. They were only given general feedback in the shape of basic comments (minimal feedback) about how well they had done (cf. Bitchener et al., 2005; Mubarak, 2013).

\subsection{Instrument of the Study}

To collect data for this study, two instruments were used: a written test, and a questionnaire about attitudes.

\subsubsection{The Writing Test}

The current investigation employed a test-retest format, requiring the students in the control and experimental groups to complete a 30-minute essay on an identical topic at the beginning and the end of the treatment period. The students were asked to complete an essay on an assigned topic (e.g., "Learning Life Skills", "College Education Prepares You for Successful Future"). Three raters (the researcher and two English language teachers) employed Paulus' (1999) rubric for evaluation of student writing performance. Paulus' (1999) rubric had 10 scales (i.e., 10 sections from one point to 10 points in six different categories of grammar, vocabulary, mechanics, organization, development, and coherence/cohesion). Using Cohen's Kappa test, the inter-rater reliability of the raters' scorings of the students' writings was checked, and it was found to be 0.89 , indicating that the three raters have provided similar evaluations of students' writing performance. Despite being similar in rating, the scores reported by the raters were added up and their average was used in statistical analyses.

\subsubsection{The Attitude Questionnaire}

The questionnaire used in this study was adapted and modified from the relevant existing questionnaires investigating the perceptions and attitudes of students about teachers' feedback (e.g., Alharbi, 2016; Hamouda, 2011; Mubarak, 2013). The questionnaire consisted of 22 items in the format of a five-point Likert scale $(5=$ strongly agree, $4=$ agree, $3=$ undecided, $2=$ disagree, and $1=$ strongly disagree). This questionnaire was developed in three similar versions according to the form of WCF each of the three groups received. The three versions of the questionnaire were prepared in English and then translated into Arabic, allowing students to comprehend the questions and give accurate responses. To ensure the validity of the instrument, a jury of six reviewers (two evaluation/assessment experts, two English-language writing teachers, and two English-language university professors) were shown the questionnaire and asked for their opinions on its accuracy, clarity, and suitability. The questionnaire then underwent review and modification in line with their suggestions. Moreover, the questionnaire was revised and piloted through using 12 students with English writing proficiency levels similar to those of the students in the current study. To further establish the reliability of the questionnaire, Cronbach-Alph was used, and the score was 0.88 .

Once the treatment was completed, the subjects were requested to complete one of the three versions of the questionnaire depending on the type of the feedback they received during the treatment period. The questionnaire was not time-limited, allowing students to answer all questions and to fully articulate their beliefs and attitudes 
regarding the types of WCF provided. Then, the scores of the questionnaires in each of the three groups were averaged in order to draw a comparison between the groups in terms of the most preferred WCF type.

\section{Results and Discussion}

The current investigation aims at studying the impact of three different types of WCF on Saudi EFL university students' writing achievement. In addition, it attempts to explore Saudi EFL undergraduates' attitudes towards the effectiveness of these different methods of WCF in improving their writing quality. Also, the study seeks to examine the relationship between students' attitudes and the actual effects of the three various feedback forms (i.e., direct, indirect, and minimal feedback) on students' writing achievements. This section presents the findings and their discussion as guided by the research questions of the study.

\subsection{First Research Question}

The first research question of the study investigates the effect of three different forms of WCF on Saudi EFL students' writing achievement. The data were gathered through a pre-test/treatment/post-test design for equivalent groups and analysed using the statistical package SPSS (V. 23). The results of Kolmogorov-Smirnov for writing test (1) and writing test (2) were $(Z=0.89, p=.17)$ and $(Z=1.14, p=.36)$, respectively, indicating the normality of distribution of scores in both writing tests. Table 1 presents the descriptive statistics of average gain scores of the three groups in the two writing tests.

Table 1. Descriptive statistics of average gain scores of the three groups in the two writing tests

\begin{tabular}{llllllllll}
\hline & & & & & \multicolumn{3}{l}{$95 \%$ Confidence Interval for Mean } & & \\
\cline { 7 - 8 } \cline { 6 - 8 } & $n$ & $M$ & $S D$ & Std. Error & Lower Bound & Upper Bound & Min & Max \\
\hline Group A & 20 & 6.57 & 1.28 & 0.41 & 6.05 & 7.09 & 4.23 & 8.41 \\
Group B & 20 & 4.92 & 2.39 & 0.66 & 3.88 & 5.97 & 1.91 & 11.91 \\
Group C & 20 & 4.72 & 1.51 & 0.46 & 4.09 & 5.35 & 2.41 & 7.18 \\
Total & 60 & 5.41 & 1.97 & 0.39 & 4.96 & 5.87 & 1.91 & 11.91 \\
\hline
\end{tabular}

As can be seen in Table 1, the form of WCF that Group A received (i.e., direct feedback) was more effective in improving students' writing quality $(M=6.57)$ than the other two forms of WCF provided to Group B (indirect feedback) and Group C (minimal feedback). The mean gain scores of Groups B and C in the writing tests were $(M=4.92)$ and $(M=4.72)$, respectively. As Table 2 shows, a one-way analysis of variances (ANOVA) was carried out to determine whether there are any statistically significant differences in average gain scores of the three groups in the two writing tests.

Table 2. ANOVA results of average gain scores of the three groups in the two writing tests

\begin{tabular}{llllll}
\hline & Sum of Squares & df & Mean Square & F & P \\
\hline Between Groups & 42.33 & 2 & 20.78 & 7.84 & .00 \\
Within Groups & 163.18 & 57 & 2.85 & & \\
Total & 205.51 & 59 & & & \\
\hline
\end{tabular}

As can be seen in Table 2, the results indicate statistically significant differences among the students' writing performance with regard to the type of WCF supplied $(F(2,57)=7.84, p=.00)$. Therefore, in order to elucidate the exact points of differences among the different forms of feedback each of the three groups received, a Tukey post hoc test was conducted. 
Table 3. Tukey post hoc test results of average gain scores of the three groups in the two writing tests

\begin{tabular}{lllllll}
\hline (I) Group & (J) Group & Mean Difference (I-J) & & & \multicolumn{2}{c}{$95 \%$ Confidence Interval } \\
\cline { 5 - 7 } Group A & Group C & $1.85^{*}$ & Std. Error & P & Lower Bound & Upper Bound \\
& Group B & $1.65^{*}$ & 0.68 & .01 & 0.76 & 3.26 \\
\multirow{3}{*}{ Group B } & Group C & 0.20 & 0.68 & .03 & 0.56 & 3.06 \\
& Group A & $-1.65^{*}$ & 0.68 & .98 & -0.89 & 1.61 \\
Group C & Group B & -0.20 & 0.68 & .03 & -2.74 & -0.24 \\
& Group A & $-1.85^{*}$ & 0.68 & .98 & -1.29 & 1.21 \\
\hline
\end{tabular}

Note. The mean difference is significant at the 0.05 level.

As can be seen in Table 3, the Tukey post hoc test conducted on the collected data shows that there were significant differences among the subjects' writing performance with regard to the type of WCF received. That is, there was significant differences not only between Groups A and C $(p=.01)$ but also between Groups A and B ( $p$ $=.03$ ), where Group A was better in both pairs. This finding indicates that the students' writing quality differed with respect to feedback and no feedback and also to the different types of feedback, i.e., indirect and direct. The difference in the achievement of the three groups of students may be attributed to the fact that the teacher's direct WCF was provided more clearly, which may have encouraged the students to deal with their writing tasks enthusiastically and therefore be reflected in better achievements. This finding lends support to other studies that found direct WCF has positive effects in helping students improve their writing quality (e.g., Aghajanloo et al., 2016; Beuningen et al., 2012; Van Beuningen et al., 2008). However, the finding contradicts that of Mubarak (2013) who found no significant differences between direct and indirect WCF on writing quality of Bahraini university media students. These varying results may be due to differences in the English proficiency levels of students in the two studies. In this study, the students have higher proficiency in English than that of students in Mubarak's (2013) study. Therefore, it is possible that the students in this study benefited from the feedback provided to them because their relatively higher level of English made them capable of understanding how the feedback could be employed to improve their writing.

\subsection{Second Research Question}

The objective of the second research question is to examine Saudi EFL university students' attitudes toward the efficacy of the three different types of WCF in improving their writing achievement. At first, to check the normality of distribution of the questionnaire data, Kolmogorov-Smirnov was executed, and the results of this test showed that the scores were normally distributed $(Z=1.06, p=.38)$.

Table 4. Descriptive statistics of students' feedback attitudes

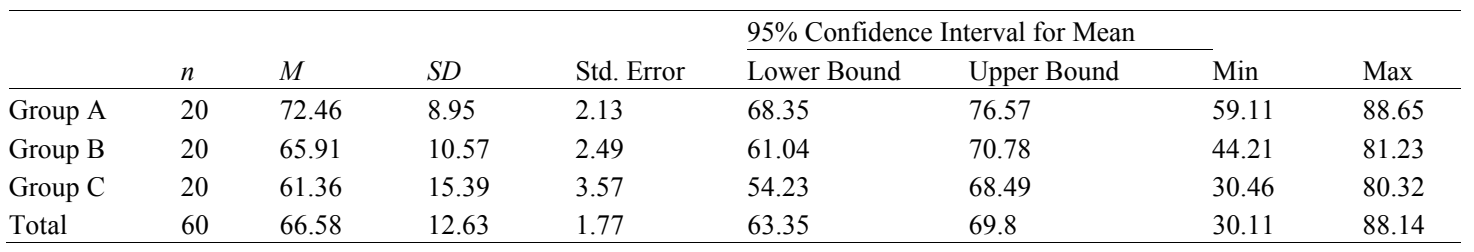

As Table 4 displays, students in Group A $(M=72.46)$, who received direct WCF, preferred this feedback type more than subjects in Group B $(M=65.91)$, who received the indirect WCF type, and subjects in Group C $(M=$ 61.36), who received minimal feedback type. Also, because the homogeneity of variances was verified $(p=.68)$, a one-way ANOVA was conducted to see if this difference was significant or not.

Table 5. ANOVA results of students' feedback attitudes

\begin{tabular}{llllll}
\hline & Sum of Squares & df & Mean Square & F & P \\
\hline Between Groups & 1355.53 & 2 & 732.82 & 4.63 & .01 \\
Within Groups & 8033.25 & 57 & 250.28 & & \\
Total & 9388.78 & 59 & & & \\
\hline
\end{tabular}

Table 5 shows statistically significant differences among the students' attitudes toward the type of feedback received by each of the three groups $(F(2,57)=4.63, p=.01)$. A Tukey post hoc test was conducted to identify 
the exact points of the differences. As can be seen in Table 6, the results of the Tukey post hoc test indicate that there are significant differences $(p=.02)$ between Groups A and C (direct WCF and minimal feedback, respectively), with Group A having the highest mean $(M=72.46)$ and Group $C$ having the lowest mean $(M=$ 61.36). This means that students' attitudes are affected by the ways of giving feedback, and therefore teachers' understanding of and responding to the preferred ways of their students can lead to promoting their positive attitudes. Teachers' lack of attention to this issue may result in making this process fails in achieving its goals. Also, giving the appropriate feedback through the most effective strategy can significantly enhance EFL students' motivation to write and can develop the quality of their writing. Moreover, the finding indicates that the Saudi EFL university students hold positive attitudes towards teachers' WCF, whether it is direct or indirect. Similar findings were also reported by other relevant studies examining students' preferences and attitudes towards teachers' WCF (e.g., Al-Sawalha, 2016; Hamouda, 2011; Katayama, 2007; Korte, 2015; Salteh \& Sadeghi, 2015; Srichanyachon, 2012; Zacharias, 2007).

Table 6. Tukey post hoc test results of students' feedback attitudes

\begin{tabular}{|c|c|c|c|c|c|c|}
\hline \multirow[t]{2}{*}{ (I) Group } & \multirow[t]{2}{*}{ (J) Group } & \multirow[t]{2}{*}{ Mean Difference (I-J) } & \multirow[b]{2}{*}{ Std. Error } & \multirow[b]{2}{*}{$\mathrm{P}$} & \multicolumn{2}{|c|}{ 95\% Confidence Interval } \\
\hline & & & & & Lower Bound & Upper Bound \\
\hline \multirow[t]{2}{*}{ Group A } & Group C & $11.01 *$ & 3.89 & .02 & 2.28 & 20.24 \\
\hline & Group B & 6.55 & 3.89 & .35 & -2.27 & 15.69 \\
\hline \multirow[t]{2}{*}{ Group B } & Group C & 4.55 & 3.89 & .61 & -4.27 & 13.69 \\
\hline & Group A & -6.55 & 3.89 & .35 & -15.37 & 2.59 \\
\hline \multirow[t]{2}{*}{ Group C } & Group B & -4.55 & 3.89 & .61 & -13.37 & 4.59 \\
\hline & Group A & $-11.01 *$ & 3.89 & .02 & -19.92 & -1.96 \\
\hline
\end{tabular}

\subsection{Third Research Question}

In order to answer the third research question of the study (i.e., correlations between students' attitudes and actual influence of the three feedback types on students' writing achievement), correlations were assessed between the average improvement for each student group over the course of the treatment and the average scores on the three versions of the attitude questionnaire they each completed. For each of the three groups, a Pearson correlation coefficient was applied to the average improvement and attitudes towards WCF in order to determine if there was any correlation between the students' attitudes towards each type of WCF and the actual influence each type of WCF on written achievement.

Table 7. Relationship between students' feedback attitudes and actual effects of different WCF types

\begin{tabular}{lll}
\hline Group & $r$ & $p$ \\
\hline Group A & $.90^{* *}$ & .00 \\
Group B & $.52 *$ & .02 \\
Group C & $.56^{*}$ & .02 \\
\hline
\end{tabular}

Note. ${ }^{* *}$ Correlation is significant at the 0.01 level (2-tailed). *Correlation is significant at the 0.05 level (2-tailed).

Table 7 indicates that the reported correlation between the attitudes of the students in Group A and the average gain scores of their writing tests was a strong, positive, and significant correlation $(r=.90)$ (Field, 2013). As for Group B $(r=.52)$ and Group C $(r=.56)$, there was a moderate, direct, and positive relationships between the attitudes of the students in each of the two groups and their writing improvement. These results suggest that there a relationship between the students' attitudes and the actual effects of three different feedback types (direct, indirect or minimal) in students' writing. Therefore, it seems that students' attitudes are an important element in the effectiveness of feedback, and therefore, to benefit students, writing teachers should not ignore their students' attitudes. Furthermore, because a strong, positive, and significant correlation was found between the most significantly positive WCF form on student writing quality and the most preferred one (both were direct WCF type), direct WCF can be considered as an ideal pedagogical solution that can be offered to Saudi EFL university students.

\section{Conclusion}

The current study examined the impact of three different methods of WCF on students' writing quality as well as students' attitudes toward the effectiveness of these WCF types in improving their writing attainment. The results 
showed that although WCF has a general positive effect in the improvement of students' overall writing quality, the results also revealed that direct WCF has a significantly greater influence in this area. Moreover, the results indicated that the students showed positive attitudes towards their teachers' WCF, and that there is a relationship between the students' attitudes and the actual effects of the three feedback types on their writing. This demonstrates that it is vital that feedback is clear and supportive because this encourages a positive attitude in students towards their teachers' feedback, which in turn will improve their writing quality.

The study aimed to contribute to the growing literature on WCF and to find solutions for improving feedback practices and EFL student writing teaching. The study, however, has a number of limitations, so caution should be taken as it might be risky to generalise based on the findings obtained. The first limitation is that the study lasted for only 13 weeks, which is probably not enough to determine whether indirect WCF feedback had an effect on students' writing quality. Another evident limitation is the absence of female subjects, because only male students were recruited in the study. If female students participated, the results might be different, in particular regarding their attitudes to the various given WCF forms. A third limitation is that the data of the study were gathered from one Saudi university. Moreover, the study recruited student participants with a relatively high English proficiency who can understand and benefit from the feedback provided. Thus, it is proposed that this study be replicated with a larger number of participants from different universities and over the whole year. In addition, it would be interesting to compare results across levels of English proficiency as well as gender. In conclusion, the findings of this study have added to the mounting body of studies examining the effect of teacher's WCF in enhancing EFL academic writing.

\section{Acknowledgments}

The author expresses his appreciation to the Deanship of Scientific Research at King Saud University, Saudi Arabia, and the Research Centre at the College of Languages \& Translation for offering support for the current article.

\section{References}

AbuSeileek, A. F. (2006). The use of word processor for teaching writing to EFL learners in King Saud University. Journal of King Saud University, 19, 1-15.

Afitska, O. (2015). Role of focus-on-form instruction, corrective feedback and uptake in second language classrooms: some insights from recent second language acquisition research. The Language Learning Journal, 43, 57-73. https://doi.org/10.1080/09571736.2012.701320

Aghajanloo, K., Mobini, F., \& Khosravi, R. (2016). The Effect of Teachers' Written Corrective Feedback (WCF) Types on Intermediate EFL Learners' Writing Performance. Advances in Language and Literary Studies, 7, 28-37. https://doi.org/10.7575/aiac.alls.v.7n.3p.28

Ahmed, A. M. (2020). Feedback in EFL Writing: Arab World Contexts, Issues, and Challenges. In A. M. Ahmed, S. Troudi \& S. Riley (Eds.), Feedback in L2 English Writing in the Arab World: Inside the Black Box (pp. 1-31). Cham: Springer International Publishing. https://doi.org/10.1007/978-3-030-25830-6_1

Al-Hazmi, S., \& Scholfield, P. (2007). Enforced revision with checklist and peer feedback in EFL writing: The example of Saudi university students. Scientific Journal of King Faisal University (Humanities and Management Sciences), 8, 237-267.

Al-Sawalha, A. (2016). EFL Jordanian students' reaction to written comments on their written work: A case study. Arab World English Journal (AWEJ), 7, 63-77. https://doi.org/10.24093/awej/vol7no1.5

Alharbi, S. H. (2016). Effect of teachers' written corrective feedback on Saudi EFL university students' writing achievements. International Journal of Linguistics, 8, 15-29. https://doi.org/10.5296/ijl.v8i5.9996

Alhaysony, M. H. (2008). Saudi-female English major students' writing strategies in L1 (ARABIC) AND L2. Unpublished master's dissertation. The University of Essex, Colchester, UK.

Alkhatib, N. (2015). Written corrective feedback at a saudi university: English language teachers' beliefs, students' preferences, and teachers' practices. Unpulished doctoral thesis. University of Essex, Colchester, UK.

Amrhein, H. R., \& Nassaji, H. (2010). Written corrective feedback: What do students and teachers think is right and why? Canadian Journal of Applied Linguistics, 13, 95-127. https://journals.lib.unb.ca/index.php/CJAL/article/view/19886

Beuningen, C. G. V., Jong, N. H. D., \& Kuiken, F. (2012). Evidence on the Effectiveness of Comprehensive 
Error Correction in Second Language Writing. Language Learning, 62, 1-41. https://doi.org/10.1111/j.1467-9922.2011.00674.x

Binglan, Z., \& Jia, C. (2010). The Impact of Teacher Feedback on the Long-term Improvement in the Accuracy of EFL Student Writing. Chinese Journal of Applied Linguistics (Foreign Language Teaching \& Research Press), 33.

Bitchener, J., \& Ferris, D. R. (2012). Written corrective feedback in second language acquisition and writing. New York: Routledge. https://doi.org/10.4324/9780203832400

Bitchener, J., \& Knoch, U. (2009a). The relative effectiveness of different types of direct written corrective feedback. System, 37, 322-329. https://doi.org/10.1016/j.system.2008.12.006

Bitchener, J., \& Knoch, U. (2009b). The value of a focused approach to written corrective feedback. ELT Journal, 63, 204-211. https://doi.org/10.1093/elt/ccn043

Bitchener, J., Young, S., \& Cameron, D. (2005). The effect of different types of corrective feedback on ESL student writing. Journal of Second Language Writing, 14, 191-205. https://doi.org/10.1016/j.jslw.2005.08.001

Chandler, J. (2003). The efficacy of various kinds of error feedback for improvement in the accuracy and fluency of L2 student writing. Journal of Second Language Writing, 12, 267-296. https://doi.org/10.1016/S1060-3743(03)00038-9

Ferris, D. (2003). Response to student writing: Implications for second language students. Mahwah, NJ: Lawrence Erlbaum. https://doi.org/10.4324/9781410607201

Ferris, D. (2011). Treatment of error in second language student writing. Ann Arbor, MI: University of Michigan Press. https://doi.org/10.3998/mpub.2173290

Ferris, D., \& Roberts, B. (2001). Error feedback in L2 writing classes: How explicit does it need to be? Journal of Second Language Writing, 10, 161-184. https://doi.org/10.1016/S1060-3743(01)00039-X

Field, A. (2013). Discovering Statistics Using IBM SPSS Statistics (4th ed.). London, UK: Sage.

Hamouda, A. (2011). A Study of Students and Teachers' Preferences and Attitudes towards Correction of Classroom Written Errors in Saudi EFL Context. English Language Teaching, 4, 128-141. https://doi.org/10.5539/elt.v4n3p128

Hyland, K., \& Hyland, F. (2019). Feedback in second language writing: Contexts and issues (2nd ed.). Cambridge, UK: Cambridge university press. https://doi.org/10.1017/9781108635547

Katayama, A. (2007). Japanese EFL students' preferences toward correction of classroom oral errors. Asian EFL Journal, 9, 289-305.

Keh, C. L. (1990). Feedback in the writing process: A model and methods for implementation. ELT Journal, 44, 294-304. https://doi.org/10.1093/elt/44.4.294

Korte, N. E. (2015). The relationship between written teacher feedback on essays and student motivation: A research synthesis. Unpublished master dissertation. Université de Sherbrooke, Quebec, Canada.

Lyster, R., \& Ranta, L. (1997). Corrective feedback and learner uptake: Negotiation of form in communicative classrooms. Studies in Second Language Acquisition, 19, 37-66. https://doi.org/10.1017/S0272263197001034

Mubarak, M. (2013). Corrective feedback in L2 writing: A study of practices and effectiveness in the Bahrain context. Unpublished. University of Sheffield, Sheffield, UK.

Nicol, D. J., \& Macfarlane, D. (2006). Formative assessment and self - regulated learning: A model and seven principles of good feedback practice. Studies in Higher Education, 31, 199-218. https://doi.org/10.1080/03075070600572090

Park, H.-S. (2010). Teachers' and learners' preferences for error correction. Unpublished master's dissertation. California State University, California State, US.

Paulus, T. M. (1999). The effect of peer and teacher feedback on student writing. Journal of Second Language Writing, 8, 265-289. https://doi.org/10.1016/S1060-3743(99)80117-9

Salteh, M. A., \& Sadeghi, K. (2015). Teachers' and Students' Attitudes toward Error Correction in L2 Writing. Journal of Asia TEFL, 12. https://doi.org/10.18823/asiatefl.2015.12.3.1.1 
Srichanyachon, N. (2012). An investigation of university EFL students' attitudes toward peer and teacher feedback. Educational Research and Reviews, 7, 558. https://doi.org/10.5897/ERR12.060

Suzuki, W. (2012). Written languaging, direct correction, and second language writing revision. Language Learning, 62, 1110-1133. https://doi.org/10.1111/j.1467-9922.2012.00720.x

Van Beuningen, C. G., De Jong, N. H., \& Kuiken, F. (2008). The effect of direct and indirect corrective feedback on L2 learners' written accuracy. ITL-International Journal of Applied Linguistics, 156, 279-296. https://doi.org/10.2143/ITL.156.0.2034439

Williams, J. (2002). Undergraduate second language writers in the writing center. Journal of Basic Writing, 21, 73-91.

Zacharias, N. T. (2007). Teacher and student attitudes toward teacher feedback. RELC Journal, 38, 38-52. https://doi.org/10.1177/0033688206076157

\section{Appendix A}

\section{Students' Feedback Attitudes Questionnaire}

\begin{tabular}{|c|c|c|c|c|c|}
\hline No. & Item & 2 & 3 & 4 & 5 \\
\hline 1 & Feedback is given on my written assignments in an appropriate way. & & & & \\
\hline 2 & Feedback is not a considerable source to improve my writing. & & & & \\
\hline 3 & Feedback is not useful at all because I cannot understand it. & & & & \\
\hline 4 & Feedback is random and includes confusing criteria for evaluation. & & & & \\
\hline 5 & I benefit from my teacher's feedback on my writing. & & & & \\
\hline 6 & I feel that my teacher's feedback helps me improve the quality of my writing. & & & & \\
\hline 7 & $\begin{array}{l}\text { I feel that my teacher's feedback increases my self-confidence when performing writing } \\
\text { tasks. }\end{array}$ & & & & \\
\hline 8 & I now can make corrections myself based on the received feedback. & & & & \\
\hline 9 & I prefer my teacher to correct all my writing errors on the script. & & & & \\
\hline 10 & I prefer not to receive feedback on my writing. & & & & \\
\hline 11 & I would like to receive more feedback on my writing in the future. & & & & \\
\hline 12 & In my experience, my teacher's feedback is very encouraging. & & & & \\
\hline 13 & My English is very weak, and I do not think I can benefit from feedback & & & & \\
\hline 14 & My teacher's feedback helps me develop strategies for generating ideas, revising, and editing. & & & & \\
\hline 15 & My teacher's feedback is too negative. & & & & \\
\hline 16 & My teacher's feedback makes writing more meaningful and enjoyable. & & & & \\
\hline 17 & My teacher's feedback motivates me to achieve a suitable level of writing proficiency. & & & & \\
\hline 18 & Feedback helps me to know what to avoid in next drafts. & & & & \\
\hline 19 & $\begin{array}{l}\text { My teacher's feedback motivates me to continuously revise my draft, which in turn helps me } \\
\text { improve my writing. }\end{array}$ & & & & \\
\hline 20 & My teacher's feedback raises my awareness of my own strengths and weaknesses. & & & & \\
\hline 21 & The feedback I received guides me on how to identify and correct my errors. & & & & \\
\hline 22 & The feedback I received is enough to show me what to do next time. & & & & \\
\hline
\end{tabular}

\section{Copyrights}

Copyright for this article is retained by the author, with first publication rights granted to the journal.

This is an open-access article distributed under the terms and conditions of the Creative Commons Attribution license (http://creativecommons.org/licenses/by/4.0/). 